\title{
Antigen-Specific Induction of Osteopontin Contributes to the Chronification of Allergic Contact Dermatitis
}

Anne M. Seier, ${ }^{*}$ Andreas C. Renkl, ${ }^{*}$

Guido Schulz, ${ }^{*}$ Tanja Uebele, ${ }^{*}$ Anca Sindrilaru, *

Sebastian Iben, ${ }^{*}$ Lucy Liaw, ${ }^{\dagger}$ Shigeyuki Kon, ${ }^{\neq}$

Toshimitsu Uede, ${ }^{\ddagger}$ and Johannes M. Weiss*

From the Department of Dermatology and Allergology,"

University of Ulm, Ulm, Germany; the Center for Molecular

Medicine, ${ }^{\dagger}$ Maine Medical Center Research Institute,

Scarborough, Maine; and the Division of Molecular

Immunology, ${ }^{\ddagger}$ Institute of Genetic Medicine, Hokkaido

University, Sapporo, Japan
Allergic contact dermatitis (ACD) is a common disease with high socioeconomic impact, and sufferers carry a heavy burden in their working and social lives. ${ }^{1}$ Once ACD against a chemical, usually a hapten, occurs, only strict allergen avoidance prevents recurrent disease. To date there is no method to reverse persistent sensitization. ${ }^{2,3}$ The prognosis of ACD with sensitization to antigens encountered in different professions is poor and often initial occurrence is followed by progressive chronic disease. ${ }^{1,4-6}$

During the sensitization phase of ACD, myeloid type dendritic cells (mDCs) of the skin, namely Langerhans cells (LCs) and dermal DCs transport haptenated peptides that have penetrated the epidermis to skin draining lymph nodes to present them to naive T cells. ${ }^{7-9}$ Antigenspecific primed $T$ cells that have acquired the ability to enter the skin through expression of cutaneous lymphocyte antigen recirculate to the skin. ${ }^{3,10,11}$ When the epidermis is again penetrated by the allergen and immediately recognized by the antigen-specific cells, a rapid expansion and attraction of additional $\mathrm{T}$ effector cells occurs, resulting in localized skin inflammation at the contact site. $^{10}$ With repeated antigen exposure, chronic stimulation of antigen-specific $T$ cells results in severe relapsing or persistent eczema. ${ }^{6}$

Contact hypersensitivity (CHS), the murine model of $A C D$, is a well established system to study immune mechanisms of delayed type hypersensitivity reactions, mediated by hapten specific T cells in the skin. ${ }^{3}$ Furthermore, the pathomechanisms that lead to chronic nonresolving ACD can be studied in this model. In mice sensitized on the abdominal skin against 2,4,6trinitrochlorobenzene (TNCB), reapplication of the hapten causes skin inflammation (acute $\mathrm{CHS}$ ) that resolves

Supported by a grant from the Landesstiftung Baden-Württemberg, "Forschungsprogramm Allergologie" grant P-LS-AL/12 (to J.M.W.). A.S. is supported by the Deutsche Forschungsgemeinschaft grant SFB497-C7.

A.M.S. and A.C.R. contributed equally to this work.

Accepted for publication September 22, 2009

Address reprint requests to Johannes M. Weiss, M.D., University of Ulm, Department of Dermatology and Allergology, Maienweg 12, 89081 Ulm, Germany. E-mail: johannes.weiss@uniklinik-ulm.de. 
within a few days. However, when the hapten is repeatedly applied, chronic inflammation is provoked (chronic $\mathrm{CHS})^{3,12}$

Osteopontin (OPN) is an acidic phosphoglycoprotein with cytokine functions under physiological or pathological conditions that is secreted by different immune cells among them T cells, macrophages, and DCs. ${ }^{13-16}$ Intracellular isoforms of OPN and secreted isoforms of OPN (sOPN) have been identified in the regulation of cellmediated immune responses. Macrophages and different DCs subsets produce both SOPN and intracellular isoforms of OPN. Differential functions of both isoforms in myeloid DCs (mDCs) and plasmacytoid DCs (pDCs) have been implicated in regulating the development of Th1 and Th17 effector cells, thereby substantially influencing cell mediated immunity in infectious, autoimmune, and allergic disease. ${ }^{17-23}$ Shinohara et al ${ }^{24}$ demonstrated that OPN gene expression in T cells is regulated by the transcription factor $\mathrm{T}$-bet that polarizes $\mathrm{T}$ helper cells toward a Th1 phenotype. T-bet-dependent expression of OPN induces the differentiation of $\mathrm{CD}_{4}^{+}$and $\mathrm{CD}^{+}{ }^{+} \mathrm{T}$ helper cells toward the Th1 or Tc1 lineage.

Overexpression of OPN especially by activated T cells is known to be associated with the aggravation of autoimmune diseases, among them systemic lupus erythematosus, inflammatory bowel disease, rheumatoid arthritis, and multiple sclerosis. ${ }^{25-30}$ OPN null mice have ameliorated disease in Th1- or Th17-dominated immune responses, such as experimental autoimmune encephalomyelitis, autoimmune keratitis, and granuloma formation, ${ }^{19,24,29,31-33}$ and are less efficient in clearing viral or bacterial disease because of a reduced T cell-mediated immune response. In experimental autoimmune encephalomyelitis models, OPN promotes the survival of T cells by modulating various signaling cascades, for example triggering the NF $\kappa$ b pathway and simultaneously inhibiting the transcription factor Foxo3a. ${ }^{31,34}$ Furthermore, through its chemotactic properties OPN attracts T cells, monocytes and DCs into inflammatory sites and induces the proangiogenic secretion of interleukin (IL)-1 $\beta$ in monocytes, an effect likely to contribute to increased microvessel formation in chronic inflammation. ${ }^{13,35}$

We previously investigated OPN function during the sensitization phase of $\mathrm{CHS}$ and found that SOPN guides LCs and mDCs into skin-draining lymph nodes, induces $\mathrm{mDC}$ activation and polarizes them toward a Th1-inducing phenotype. ${ }^{36,37}$ Further, we found that OPN null mice are reduced in their capacity to mount full acute $\mathrm{CHS}$ response. ${ }^{22}$ Assuming that OPN secretion is important for the elicitation phase and the chronification of delayed type allergic disease, we studied OPN expression and cell specificity in chronic ACD. We found high levels of OPN secretion on antigen-specific stimulation by memory T cells. In turn Th1 cell-derived interferon- $\gamma$ (IFN- $\gamma$ ) specifically induced OPN in activated keratinocytes. Finally, antigen-specific OPN expression was important for chronification of ACD in vivo, because OPN null mice have a reduced antigen-specific chronic $\mathrm{CHS}$ response and established chronic inflammation is in part suppressed by anti-OPN antibodies.

\section{Materials and Methods}

\section{Media and Reagents}

RPMI 1640 was supplemented (c-RPMI) with 10\% heatinactivated FCS, $1 \%$ nonessential amino acids, $1 \%$ penicillin and streptomycin, 1\% L-glutamine, 1\% HEPES buffer, and 1\% sodium pyruvate (all from Life Technologies, Eggenstein, Germany). For Th-polarization assays, c-RPMI was supplemented with $5 \times 10^{-5} \mathrm{M}$ mercaptoethanol (Sigma-Aldrich, Taufkirchen, Germany). For culture of human $T$ cells the above medium was used with $5 \%$ heat inactivated human serum. Monoclonal antibodies specific for OPN (MPIIIB10 (1)) were purchased from Developmental Studies Hybridoma Bank at the University of lowa. The anti-human integrin antibodies: $\alpha_{\mathrm{v}} \beta_{3}$ (LM609), $\alpha_{\mathrm{v}} \beta_{5}$ (P1FG), $\beta 1$ (P4G11), $\alpha_{4}$ (9F10), $\alpha_{9} \beta_{1}$ (Y9A2), and CD45RO (UCHL1) were obtained from Chemicon International (Schwalbach, Germany); CD44s (SFF-2) and CD44v6 (VFF-18) from Bender MedSystems (Vienna, Austria); CD4 (RPA-T4), $\alpha 4$ (9F10), IFN- $\gamma-\mathrm{R}$ (GIR-94), and isotype control antibodies (mouse IgM (G155-228)), mouse $\operatorname{lgG}_{1}$ (107.3), and mouse $\operatorname{lgG}_{2 a}$ (MOPC-21)) were from BD Pharmingen (Heidelberg, Germany). The phosphatidylethanolamine-conjugated antimurin antibody CD4 (GK1.5) was obtained from Miltenyi Biotec (Bergisch Gladbach, Germany) and the fluorescein isothiocyanate- or antigen-presenting cell-conjugated anti-murine antibody CD8a (53-6.7) from BD Pharmingen.

Monoclonal anti-OPN antibody 35B6 (IgG1) was obtained by immunizing mice with the synthetic peptide VDVPNGRGDSLAYGLR corresponding to the internal sequence of murine OPN. The antibody 5A1 was obtained by immunizing mice with the synthetic peptide IPVKQADSGSSEEKQ corresponding to the internal sequence of human OPN. ${ }^{38}$

\section{Tissue Donors}

The study was approved by the Ethics Committee of the University of Ulm. Formal written consent was obtained from all donors. Skin specimens were obtained by standard biopsy procedures. Biopsies from of acute eczema were taken from patients that underwent routine path testing with $5 \% \mathrm{NiSO}_{4}$ in vaselinum album (Almirall Hermal, Reinbek, Germany), 24 hours after application of the allergen that had at least double-positive reactions $(++)$ with erythema, infiltration, papules, and vesicles. ${ }^{6}$ Chronic eczema specimens were obtained from patients with long-lasting chronic contact dermatitis of the hands with multiple sensitizations against delayed-type allergens before treatment. Plasma samples for OPN enzymelinked immunosorbent assay (ELISA) were obtained from patients with long-lasting severe chronic ACD of the hands and/or feet or healthy controls without history of eczema. Blood samples for T cell activation assays were obtained from volunteers with sensitization against $\mathrm{NiSO}_{4}$, verified by positive patch test or nickel patch test negative donors as controls. 


\section{Immunohistochemistry}

Immunohistochemistry was performed as described previously. ${ }^{22}$ In brief, paraffin embedded sections were pretreated by pressure cooker heating using Dako S1699 target retrieval buffer according to the manufacturers protocol (Dako, Glostrup, Denmark). Following the application of the primary antibody against OPN, $\alpha_{\mathrm{v}} \beta_{3}, \beta_{5}$, CD44s, or CCD44v6, staining was visualized by EnVision detection system (Dako) with 3,3'-diaminobenzidine chromogen as a chromogen for the peroxidase reaction. For double staining, the primary antibody was visualized by EnVision detection system with 3,3'-diaminobenzidine chromogen as a chromogen (brown) and the antibody against the second antigen was visualized with Dako REAL APAAP (Dako) using New Fuchsin substrate (red) System (Dako). Slides were photographed with an Olympus AX70 Microscope, (Olympus, Hamburg, Germany) scanned, and assembled with Corel Draw (Corel, Unterschleissheim, Germany).

\section{Antigen-Specific Stimulation of Human T Cells}

Peripheral blood mononuclear cells (PBMCs) were isolated from blood of nickel-allergic patients or healthy donors by Ficoll gradient centrifugation as described previously. ${ }^{39} \mathrm{CD} 4^{+}$or $\mathrm{CD} 8^{+}$cells were isolated with the CD4- or CD8-negative isolation kit (Miltenyi Biotec) from PBMCs according to the manufacturer's protocol. Autologous $\mathrm{CD} 14^{+}$monocytes were used as antigen-presenting cells, which were isolated from PBMCs by positive selection with anti-CD14 microbeads (Miltenyi Biotec). A total of $8 \times 10^{4} \mathrm{CD} 4^{+}$or $\mathrm{CD} 8^{+} \mathrm{T}$ cells were cultured with $2 \times 10^{4} \mathrm{CD}_{14^{+}}$monocytes with or without $10^{-4} \mathrm{M} \mathrm{NiSO}_{4}$. Nickel-specific proliferation was assessed by $\left[{ }^{3} \mathrm{H}\right]$ thymidine incorporation. OPN production was analyzed after 48 hours by ELISA (IBL, Takasaki, Japan).

\section{Human T Cell Clones}

T cell clones were established from the peripheral blood of patch test-positive donors with a history of ACD against nickel as described previously. ${ }^{40}$ In brief, bloodderived T cells were stimulated twice with $10^{-4} \mathrm{M} \mathrm{NiSO}_{4}$ and subsequently cloned by limiting dilution. Cells were plated in 60-well Terasaki microplates (Greiner bio-one, Frickenhausen, Germany) (0.5 cells/well, c-RPMI 1640) with $2 \times 10^{4}$ irradiated allogeneic feeder cells per well, $100 \mathrm{U} / \mathrm{ml}$ human IL-2 (PeproTech, London, UK), and 1 $\mu \mathrm{g} / \mathrm{ml}$ phytohemagglutinin. T cell clones were cultured with IL-2 and stimulated with phytohemagglutinin and feeder cells twice a month. The antigen-specific proliferation and OPN production of the clones was assessed using irradiated autologous PBMCs in presence or absence of $10^{-4} \mathrm{M} \mathrm{NiSO}_{4}$. After 48 hours, supernatants were harvested and analyzed for cytokine expression.

\section{Cytokine Activation of Human Keratinocytes}

Keratinocytes were generated as described previously. ${ }^{41}$ In brief, foreskin tissue was cut into small pieces $(2 \times 2$ $\mathrm{mm})$. To separate the epithelium from the underlying fibrous connective tissue, skin was treated with $6 \mathrm{mg} / \mathrm{ml}$ dispase (BD Biosciences, Heidelberg, Germany) for 12 hours at $4^{\circ} \mathrm{C}$. The epithelium dissociated and was incubated at $37^{\circ} \mathrm{C}$ in $5 \mathrm{ml}$ of trypsin-EDTA $(0.05 \%$ trypsin and $0.53 \mathrm{mmol} / \mathrm{L}$ EDTA) for 10 minutes. The isolated keratinocytes were grown to $70 \%$ confluence in keratinocyte growth medium 2 (Promocell) and were used for experiments from passages 3 to 6 . For stimulation experiments keratinocytes were stimulated for $1.5,3,6,12$, and 36 hours with IFN- $\gamma(200 \mathrm{U} / \mathrm{ml}), \mathrm{IL}-1 \alpha(10 \mathrm{ng} / \mathrm{ml}), \mathrm{IL}-1 \beta(200$ $\mathrm{U} / \mathrm{ml})$, TNF- $\alpha(1000 \mathrm{U} / \mathrm{ml}), \mathrm{IL}-12(20 \mathrm{ng} / \mathrm{ml}), \mathrm{IL}-4$ (12.5 $\mathrm{ng} / \mathrm{ml}$ ), IL-17 (50 ng/ml) (all from PeproTech) or phorbol myristate acetate $\left(10^{-7} \mathrm{M}\right.$, Sigma-Aldrich, Munich, Germany) and ionomycine (1 $\mu \mathrm{g} / \mathrm{ml}$; Calbiochem, Darmstadt, Germany). Quantitative real-time PCR of cells harvested on the indicated days was performed with a LightCycler (Roche Diagnostics, Grenzach-Wyhlen, Germany).

\section{Mice}

The mice lacking the functional OPN gene (spp1) were described previously. ${ }^{42}$ For all experiments, C57BL/6 OPN-mutant mice and their wild-type littermates in the ninth generation of backcrossing were used. For T cell transfer experiments C57BL/6 RAG2 ${ }^{-1-}$ mice were used. All animal protocols were approved by the Committee of Animal Research (Regierungspräsidium Tuebingen, Germany), which are in accordance with National Institutes of Health guidelines.

\section{Chronic CHS and Antibody Treatment}

Induction of chronic $\mathrm{CHS}$ was performed as described previously. ${ }^{12}$ In brief, 6-week-old C57BL/6 OPN-mutant mice or wild-type littermates were painted on their abdominal skin with $100 \mu$ l of $7 \%$ TNCB in acetone at day 0 . On day 7 , mice were challenged by painting $10 \mu \mathrm{l}$ of $1 \%$ TNCB on both sides of the ears. Challenge was repeated three times a week for 28 days. Ear thickness was measured with an engineer's micrometer (Mitutoyo, Neuss, Germany) before and at days 7, 8, 9, 16, 17, 18, 28, 29, and 30 , and ear-swelling was calculated. ${ }^{43}$

For antibody treatment of chronic $\mathrm{CHS}$, mice were sensitized on day 0 , first challenged on day 5 , followed by rechallenge every second day. A total of $400 \mu \mathrm{g}$ of anti-OPN 35B6 monoclonal antibody that recognizes the GDSLAYGLR epitope or isotype matched control antibody 5K1 was injected i.p. on days 10, 13, and 16 .

\section{Adoptive Transfer of T Cells into RAG2 ${ }^{-/-}$Mice}

Lymph node T cells from TNCB-sensitized OPN-mutant or wild-type C57BL/6 mice were enriched using Pan T cell isolation kit (Miltenyi Biotec). The purity of T cells was typically $\geq 95 \%$ CD3-positive cells. Purified T cells were washed three times with sterile PBS, and $10^{7}$ cells were injected i.v. in $0.25 \mathrm{ml}$ of sterile PBS into the tail vein of $\mathrm{RAG2}^{-1-}$ mice. Twelve hours after injection an acute $\mathrm{CHS}$ response was induced as described above. 


\section{Single-Cell Suspension of Ear Skin}

Mice were sacrificed and ears were cut off the base and split into dorsal and ventral halves with forceps. Dorsal halves of both ears (epidermis and dermis without cartilage) were cut into small pieces and incubated in HBSS with $1.5 \mathrm{mg} / \mathrm{ml}$ collagenase and $0.5 \mathrm{mg} / \mathrm{ml}$ hyaluronidase for 1 hour at $37^{\circ} \mathrm{C}$ on a shaker. The resulting cell suspension was passed through a 40- $\mu \mathrm{m}$ cell strainer and washed three times with PBS, followed by FACS analysis for CD8- or CD4-positive T cell numbers.

\section{Antigen-Specific Stimulation of Murine T Cells}

Murine T cells were obtained from 6-week-old C57BL/6 mice 24 hours after the initial elicitation of $\mathrm{CHS}$ with TNCB. Splenic cells of the same mice served as antigenpresenting cells and were loaded with $7 \mathrm{mmol} / \mathrm{L}$ 2,4,6trinitrobenzene sulfonic acid (TNBS) for 15 minutes at $37^{\circ} \mathrm{C}$. For antigen-specific stimulation, $2 \times 10^{5}$ lymph node cells were incubated with $2 \times 10^{5}$ untreated or TNBS-loaded irradiated splenic cells. For viability control concavalin A $(5 \mu \mathrm{g} / \mathrm{ml})$ was added. $\mathrm{CD}^{+}$or $\mathrm{CD}^{+}$cells were isolated from lymph nodes with the CD4- or CD8anegative isolation Kit (Miltenyi Biotec) according to the manufacturer's protocol. A total of $1 \times 10^{5} \mathrm{CD}^{+}$or $\mathrm{CD}^{+}$ $\mathrm{T}$ cells was incubated with $1 \times 10^{5}$ untreated or TNBSloaded irradiated splenic cells. At the indicated time points, supernatants were analyzed by OPN ELISA (IBL), and cells were collected for RNA isolation and quantitative realtime-PCR. Proliferation was assessed by $\left[{ }^{3} \mathrm{H}\right]$ thymidine incorporation.

\section{Flow Cytometry}

Surface receptor expression on T cells was determined by a standard protocol. Cells were stained $\left(4^{\circ} \mathrm{C}, 30 \mathrm{~min}-\right.$ utes) with fluorescein isothiocyanate- or phosphatidylethanolamine-labeled $\mathrm{mAb}$. A total of $0.1 \mu \mathrm{g} / \mathrm{ml}$ propidium iodide (Sigma-Aldrich) was added to exclude dead cells by appropriate gating. 5 to $10 \times 10^{3}$ or in case of skin cell suspension up to $5 \times 10^{5}$ viable cells/sample were analyzed and mean fluorescence intensities determined by CellQuest software.

\section{Proliferation Assay}

For analyzing antigen-specific proliferation T cells were cultured with antigen-presenting cells in presence or absence of antigenic stimulants. After 32 hours, co-cultures were pulsed with $1 \mu \mathrm{Ci} /$ well $\left[{ }^{3} \mathrm{H}\right]$ thymidine for 18 hours at $37^{\circ} \mathrm{C}$. Plates were harvested with a Cell Harvester (Inotech, Nabburg, Germany) compared with filter mates (PerkinElmer, Waltham, MA) and $\left.{ }^{3} \mathrm{H}\right]$ thymidine incorporation was determined by liquid scintillation spectroscopy using a beta counter 1450 Microbeta Trilux (PerkinElmer).

\section{Cytokine Measurement}

Supernatants from stimulated T cells or T cell clones were harvested at the indicated time points and stored at $-80^{\circ} \mathrm{C}$. Cytokines were quantified by ELISA according to the manufacturer's instructions and measured at an extinction of $450 \mathrm{~nm}$ (MR5000 ELISA-reader and BioLinxTM Software; Dynatech, Chantilly, VA). The following ELISA kits were used (sensitivity): OPN (5 ng/ml) from IBL, IL-4 (7.8 pg/ml), IFN- $\gamma(4.7 \mathrm{pg} / \mathrm{ml})$, all Opteia from BD Pharmingen.

\section{RNA Isolation and Quantitative Real-Time PCR}

RNA isolation of human tissue was performed using TissueLyser (Qiagen, Hilden, Germany) and RNeasy mini kit (Qiagen) according to manufacturer's instructions. Cultured cells were lysed and homogenized using Qiagen QIA-shredder (Qiagen) columns and RNA isolation was performed using the Qiagen RNeasy mini kit. To synthesize cDNA reverse transcription was performed with Omniscript RT kit (Qiagen). Obtained cDNA was used for quantitative real-time PCR with QuantiTect SYBR Green PCR kit and a LightCycler (Roche Diagnostics). Thermocycling conditions: hold at $95^{\circ} \mathrm{C}$ for 15 minutes, 40 cycles of $95^{\circ} \mathrm{C}$ for $15 \mathrm{sec}-$ onds, $60^{\circ} \mathrm{C}$ for 20 seconds, and $72^{\circ} \mathrm{C}$ for 10 seconds followed by melting curve. The relative expression of target gene in different samples was normalized to the endogenous glyceraldehyde-3-phosphate dehydrogenase and was calculated with the $2^{-\Delta \Delta c t}$ method. ${ }^{44}$ Human OPN primers were 5'-AAGAAGTTTCGCAGACCTGACATC-3' (forward) and 5'-GATGGCCTTGTATGCACCATTC-3' (reverse). Human glyceraldehyde-3phosphate dehydrogenase primers were 5'-GCAAATTCCATGGCACCGT-3' (forward) and 5'-GCCCCACTTGATTTTGGAGG-3' (reverse). Mouse OPN primers were 5'-GGTGATAGCTTGGCTTATGGACTG-3' (forward) and 5'-GCTCTTCATGTGAGAGGTGAGGTC-3' (reverse). Mouse glyceraldehyde-3-phosphate dehydrogenase primers were 5'-TGGCCTTCCGTGTTCCTACC-3' (forward) and 5'-GGTCCTCAGTGTAGCCCAAGATG-3' (reverse).

\section{Recombinant OPN Expression in Eukaryotic Cells}

Construction of expression plasmid: Human OPN was amplified with upper primer 5'-GGGCTCTGGCTAGCATACCAGTTAAACAGGCTGATTCTGGAAG-3' and lower primer 5'-CGGGATCCTTAGTGGTGGTGGTGGTGGTGACTCCCATTGACCTCAGAAGATGC-3' . ${ }^{45}$ The correct sequence was confirmed by DNA sequencing with an ABlprism sequencer (PerkinElmer). Resulting fragments were cloned into the episomal expression vector pCEP-Pu using restriction sites Nhel/BamHI. Escherichia coli strain JM109 was used for transformation and propagation of vector constructs. Proteins were expressed in frame with BM-40 signal peptide and $6 \times$ Histidin-tag using human embryonic kidney cells. 

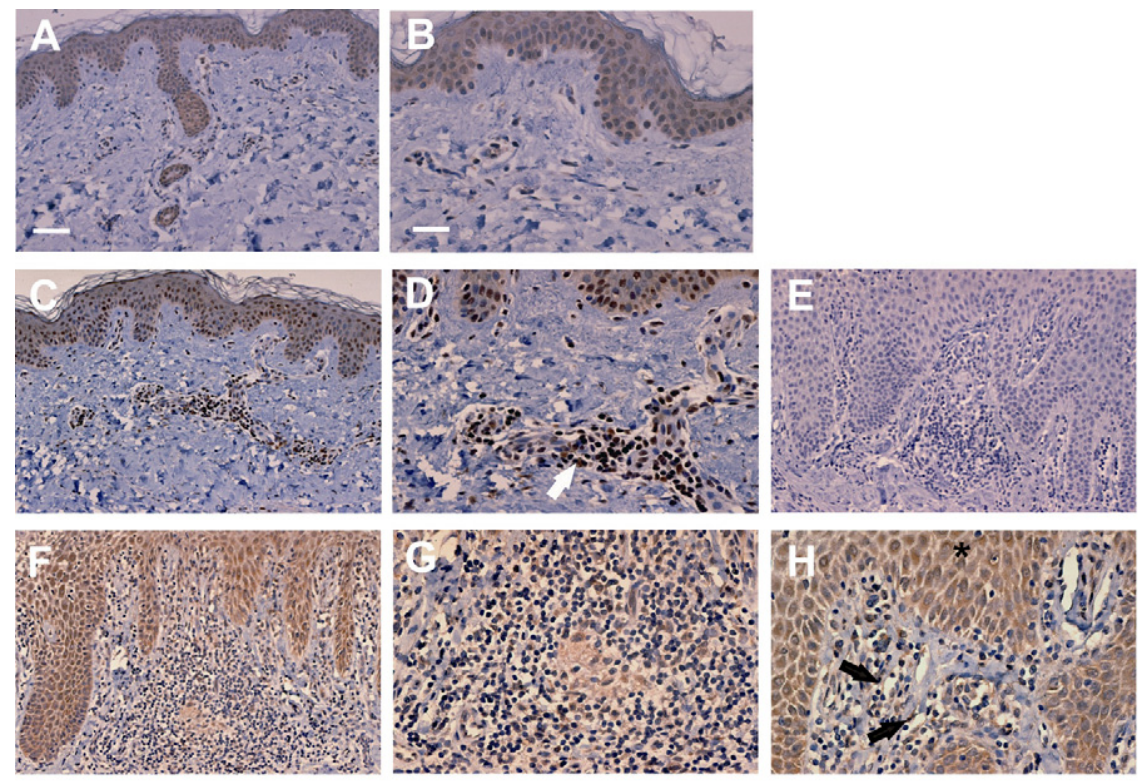

OPN

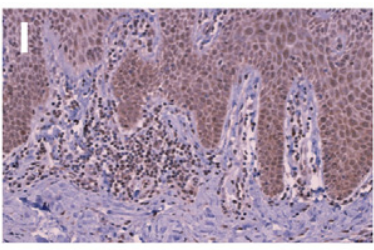

OPN
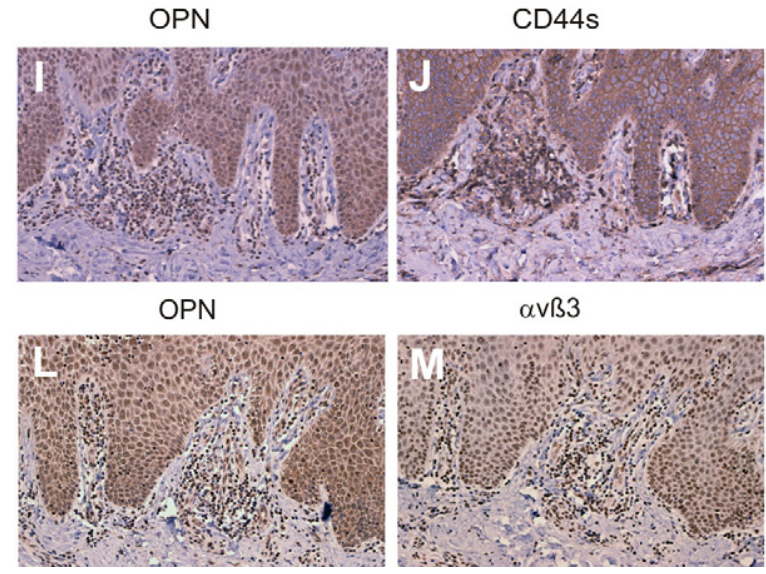

$\alpha \vee ß 3$

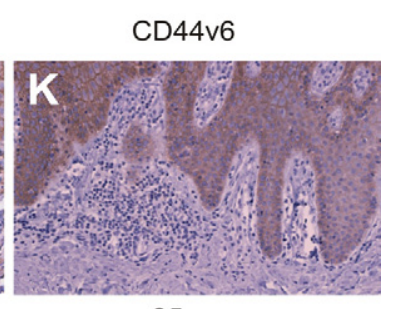

ß5
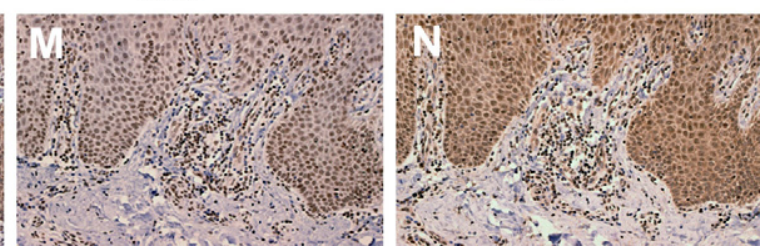

Figure 1. OPN and its receptors are abundantly expressed in chronic allergic contact dermatitis by infiltrating inflammatory cells and keratinocytes. Immunohistochemical staining of skin biopsies was performed with mAb MPIIIB10 against OPN (brown stain) in normal skin (A and B). A similar staining pattern was also observed for the OPN antibody 10A16 (IBL, data not shown). $\mathbf{C}$ and $\mathbf{D}$ : Acute allergic contact dermatitis (arrow). OPN-expressing infiltrating inflammatory cells. F-H: Chronic allergic contact dermatitis,(arrow) OPN-expressing endothelial cells, and (asterisk) OPN-expressing keratinocytes. E Chronic allergic contact dermatitis stained with primary isotype control antibody. Serial sections of skin biopsies from donors with chronic allergic contact dermatitis were stained with anti OPN antibody (I and $\mathbf{L}$ ), anti CD44 antibody $(\mathbf{J})$, antiCD44v6 antibody (K), anti- $\alpha_{\mathrm{v}} \beta_{3}$ antibody (M), or anti- $\beta_{5}$ integrin antibody $(\mathbf{N})$. A, $, \mathbf{C}, \mathbf{F}, \mathbf{E}, \mathbf{I}$, and $\mathbf{J}-\mathbf{N}$ : Representative bar in $\mathbf{A}$ corresponds to $80 \mu \mathrm{m}$. $\mathbf{B}$, $\mathbf{D}, \mathbf{E}, \mathbf{G}$, and $\mathbf{H}$ : Representative bar in $\mathbf{B}$ corresponds to $40 \mu \mathrm{m}$. Representative data from 5 donors each with chronic and acute ACD and 10 healthy donors.

\section{Cell Culture, Transfection, and Protein Expression}

Human embryonic kidney cells expressing the EBV-encoded nuclear Ag-1 protein of Epstein-Barr virus (HEK293-EBNA) (Invitrogen, Paisley, Scotland) were cultured in Dulbecco's modified Eagle's medium:F12 (Invitrogen) supplemented with $10 \%$ fetal bovine serum (PAA Laboratories, Pasching, Österreich), 1\% glutamine, and 10 $\mu \mathrm{g} / \mathrm{ml}$ penicillin/streptomycin (Biochrom, Berlin, Germany). Cells were transfected with vector constructs and selected with $2 \mu \mathrm{g} / \mathrm{ml}$ puromycin (Sigma-Aldrich) as described previously. ${ }^{46}$ Confluent bulk cultures of transfected cells were used for protein expression. Serum-free medium was collected from cultures, and new serum-free medium was added every 48 hours. Harvested medium was centrifuged at $2500 \times g$ for 10 minutes, buffered in $20 \mathrm{mmol} / \mathrm{L}$ HEPES ( $\mathrm{pH} \mathrm{7.1)}$ (Biochrom), and stored at $-80^{\circ} \mathrm{C}$. Harvested medium containing recombinant protein was sterile filtered, dialyzed against $50 \mathrm{mmol} / \mathrm{L}$ Tris ( $\mathrm{pH}$ 7.9), and passed over a column of DEAE-Sepharose (Amersham Biosciences, Uppsala, Sweden). The protein was eluted with $500 \mathrm{mmol} / \mathrm{L} \mathrm{NaCl}$. Purification of human
OPN-6x His-tag was performed by using His Bind Purification Kit (Novagen, Darmstadt, Germany) according to the manufacturer's instructions. The fractions containing the purified protein were dialyzed against $20 \mathrm{mmol} / \mathrm{L}$ Tris $(\mathrm{pH} 7.4)$ and $2 \mathrm{mmol} / \mathrm{L} \mathrm{CaCl}_{2}$ and analyzed using SDSPAGE, followed by immunoblot with anti His antibody (13/45/31) and polyclonal horseradish peroxidase-conjugated anti-mouse IgG (both Dianova, Hamburg, Germany) or silver staining.

\section{Results}

\section{OPN and OPN Receptors Are Expressed in Acute and Chronic Lesions of ACD}

To determine the expression of OPN in acute and chronic $A C D$, skin biopsies were stained by immunohistochemistry for OPN and OPN receptors. Compared with normal skin (Figure 1, A and B) of the same donor (Figure 1, $\mathrm{C}-\mathrm{E})$, OPN was primarily expressed in the inflammatory infiltrate in acute ACD lesions while only minimal staining was detectable within the epidermis. In chronic ACD 


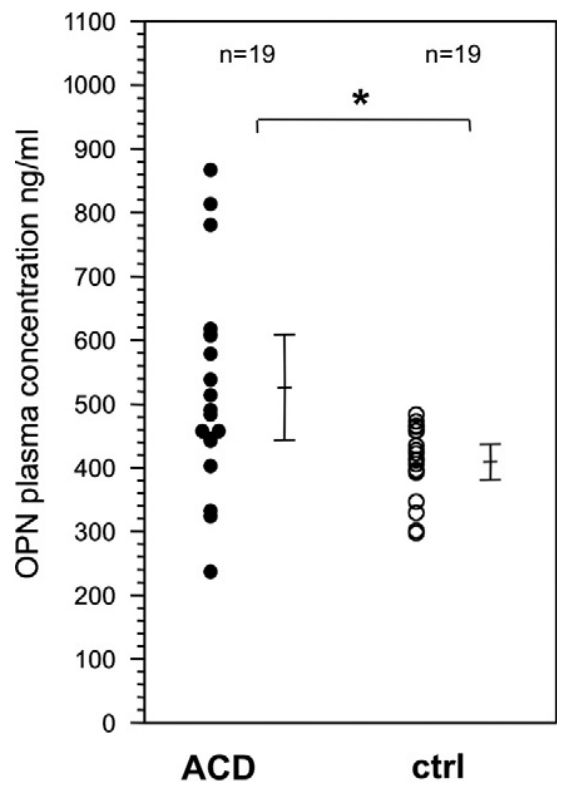

Figure 2. Patients with chronic allergic contact dermatitis have elevated OPN plasma concentrations. OPN concentration was measured in plasma from 19 healthy volunteers ( 10 male, 9 female, average age 45.8 years) and from 19 donors with allergic contact dermatitis ( 6 male, 13 female, average age 42.7 years) by OPN ELISA (IBL). Arrow bars indicate the SD The differences between both groups are statistically significant: ${ }^{*} P=0.007$, Mann-Whitney rank-sum test.

lesions, in addition to abundant OPN expression throughout the inflammatory infiltrate and on microvascular endothelial cells within the infiltrate, OPN was detected throughout the epidermis (Figure 1, F-H). Analysis of serial sections revealed that OPN-expressing inflammatory cells and keratinocytes also express the OPN receptors CD44s, CD44v6, and $\beta_{5}$ integrin (Figure 1, I-N). Membrane associated $\alpha_{\mathrm{v}} \beta_{3}$ was expressed in the inflammatory infiltrate. Within the epidermis $\alpha_{\mathrm{v}} \beta_{3}$ was detected especially in basal areas. This pattern was confirmed by immunofluorescence staining of cryosectioned specimen (data not shown). The partial nuclear staining of this antibody was only observed in the paraffin embedded sections and was regarded as background staining. The CD44v6 epitope was predominantly expressed by keratinocytes, however, rarely by the inflammatory cells (Figure $1 \mathrm{~K})$.

Especially in patients with autoimmune disease, active disease has been associated with high OPN plasma levels. ${ }^{25,26,47}$ Compared with age and gender matched healthy donors we detected significantly elevated OPN plasma levels in patients with chronic ACD (Figure 2). These findings suggest that OPN is highly expressed in ACD and contributes to the chronification of the disease.

\section{$\mathrm{CD}_{4} \mathrm{RO} \mathrm{O}^{+}, \mathrm{CD} 8^{+}$, and $\mathrm{CD} 4^{+} \mathrm{T}$ Cells Form Nickel-Allergic Donors Secrete OPN on Antigen-Specific Stimulation}

To determine which cells within the inflammatory infiltrate are the major OPN-producing cells, immunohistochemical double staining of chronic ACD lesions was per-

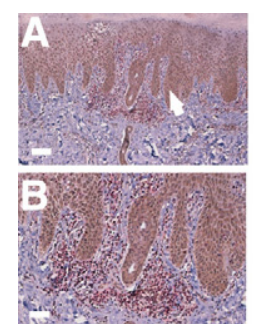

D
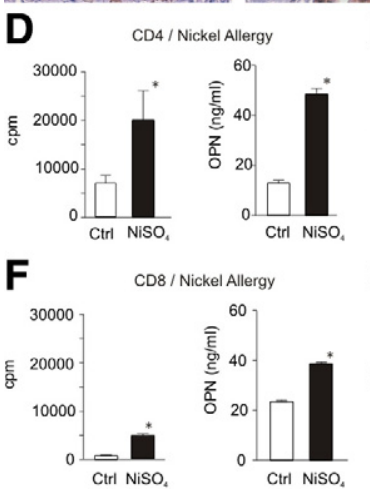

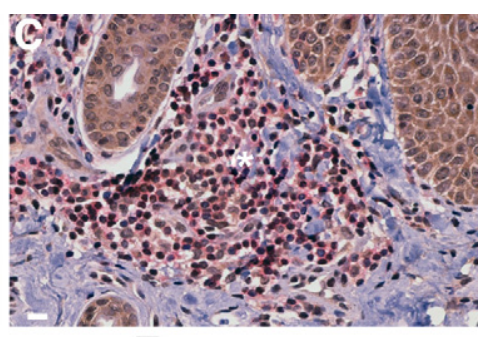

E

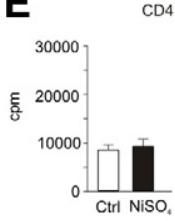

$\mathrm{CD} 4$ / Control
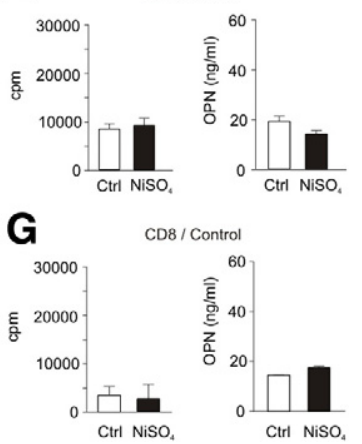

Figure 3. Antigen-specific proliferating $\mathrm{CD}^{+}$and $\mathrm{CD}^{+}$memory $\mathrm{T}$ cells from nickel-allergic donors secrete OPN. Immunohistochemical double staining of paraffin sections from biopsies of chronic allergic contact dermatitis was performed with antibodies specific for OPN (MPIIB10, brown, Envision; Dako) and CD45RO (red, APAAP; Dako) for memory T cells. In chronic allergic contact dermatitis $\mathrm{CD} 45 \mathrm{RO}^{+}$memory $\mathrm{T}$ cells (asterisk) and keratinocytes (arrow) express OPN. Magnifications: $\times 10(\mathbf{A}), \times 20(\mathbf{B})$, and $\times 40(\mathbf{C})$. Representative data from five donors. Scale bars correspond to 80 $\mu \mathrm{m}$ in $\mathbf{A}, 40 \mu \mathrm{m}$ in $\mathbf{B}$, and $25 \mu \mathrm{m}$ in $\mathbf{C}$. PBMCs from nickel-allergic donors (D and $\mathbf{F}$ ) with positive patch test to $\mathrm{NiSO}_{4}$ and healthy donors ( $\mathbf{E}$ and $\mathbf{G}$ ) with negative patch test were generated by gradient centrifugation and $\mathrm{CD}_{4}^{+}(\mathbf{D}$ and $\mathbf{E}$ ) or $\mathrm{CD}^{+} \mathrm{T}$ cells $(\mathbf{F}$ and $\mathbf{G}$ ) were purified by MACS negative depletion (purity $>95 \%$ ). Antigen-specific proliferation was determined by $\left[{ }^{3} \mathrm{H}\right]$ thymidine incorporation (D-G). Forty-eight hours after stimulation with $\mathrm{NiSO}_{4}$ supernatants were obtained and subjected to OPN-specific ELISA. Representative results for eight donors.

formed. $\mathrm{CD}_{45 \mathrm{RO}^{+}}$cells, which are predominantly memory $T$ cells, express OPN (Figure 3, A-C). We were now interested to investigate whether OPN expression by memory $T$ cells could be induced by antigen-specific activation. When PBMC from patch test positive nickelallergic donors were stimulated by $\mathrm{NiSO}_{4}$ both $\mathrm{CD}^{+}$and $\mathrm{CD}^{+}{ }^{+} \mathrm{T}$ cells sOPN (Figure $3, \mathrm{D}$ and $\mathrm{F}$ ), whereas $\mathrm{T}$ cells from healthy non nickel sensitized donors did not (Figure $3, E$ and $G$ ). Our findings indicate that OPN is induced in $T$ cells on antigen-specific activation. This is in accordance to the original observation that OPN expression is strongly induced in activated $T$ lymphocytes, as reflected in one of its names, Early T Iymphocyte activation 1.48

\section{OPN Secretion of Nickel-Specific T Cell Clones Correlates with Their Cytokine Phenotype}

To investigate how OPN secretion is correlated with the phenotype of antigen-specific T cells, we generated six T cell clones from the peripheral blood of nickel-allergic donors. All generated T cell clones were CD4 ${ }^{+}$. As expected and previously described the clones showed varying phenotypes. ${ }^{49}$ When investigating the OPN expression of such clones, we found that two clones that produced a Th1 cytokine pattern with higher amounts of IFN- $\gamma$-secreted lower amounts of OPN, as shown for rep- 

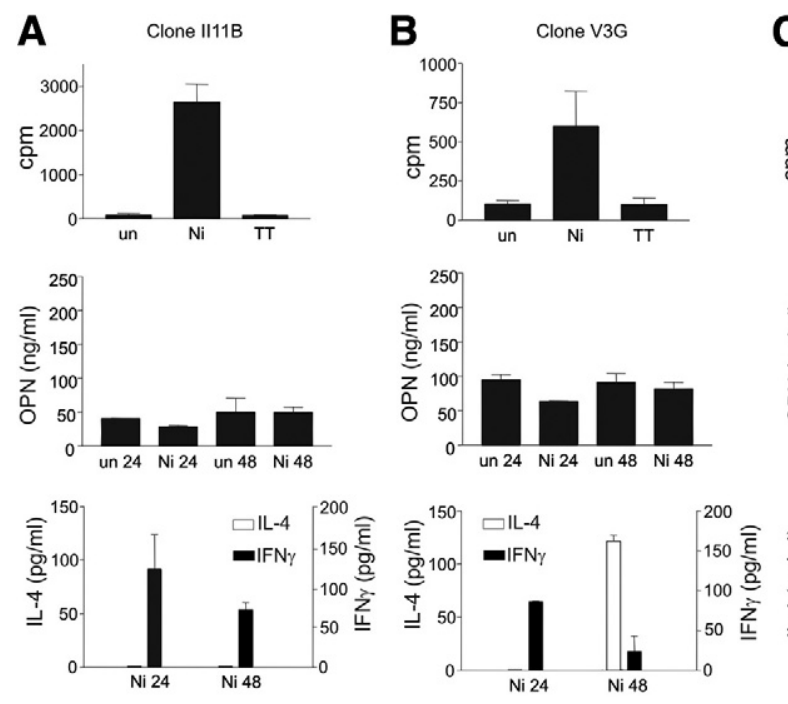

D

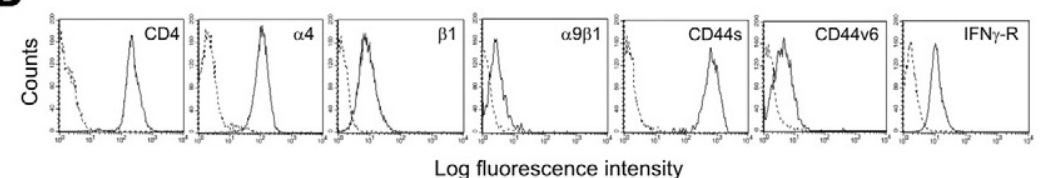

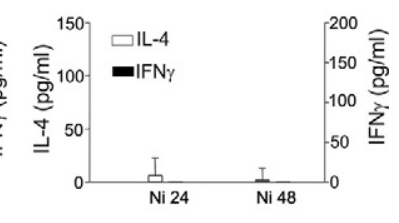
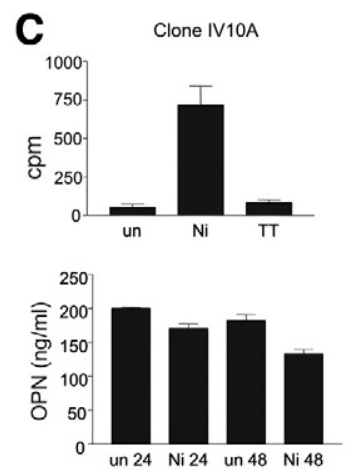

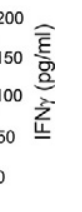

Figure 4. OPN expression by memory $\mathrm{T}$ cell clones correlates with their cytokine expression pattern. $\mathrm{CD}^{+}{ }^{+} \mathrm{CD} 45 \mathrm{RO}^{+} \mathrm{T}$ cell clones were generated from peripheral blood of nickel-allergic donors, identified by $\mathrm{NiSO}_{4}$ patch testing, as described in Materials and Methods. $\mathrm{NiSO}_{4}$ specific proliferation was measured by $\left[{ }^{3} \mathrm{H}\right]$ thymidine incorporation. Following antigen-specific stimulation, the secretion of OPN, IFN- $\gamma$, and IL- 4 was measured by ELISA. Abbreviations: un, unstimulated; $\mathrm{Ni}$, stimulated with $\mathrm{NiSO}_{4}$; TT, stimulated with tetanus toxoid. Cytokine expression was analyzed 24 and 48 hours after $\mathrm{NiSO}_{4}$ stimulation. Data for three representative clones $(\mathbf{A}-\mathbf{C})$ of a total of six analyzed clones established from two donors are shown. D: FACS analysis of the indicated OPN receptors on a $\mathrm{CD}^{+} \mathrm{T}$ cell clone IV10A. Representative data for three clones. resentative clone $1111 \mathrm{~B}$ in Figure 4A. Two clones with a Th0 cytokine pattern secreted intermediate amounts of OPN as shown for clone V3G in Figure 4B that produced both IL-4 and IFN- $\gamma$ on antigen-specific stimulation. However, two other clones for which IV10A in Figure $4 \mathrm{C}$ is representative that produced low levels of IFN- $\gamma$ and some IL-4 (indicating a Th2 phenotype) secreted comparably high amounts of OPN (Figure 4C). In none of the clones did we find modulation of OPN expression by the antigen (Figure 4, A-C). We speculate that this was due to the consolidated phenotype of the clones following repeated IL-2 restimulation during their establishment. These findings indicate that the amount of OPN secretion correlates with a certain phenotype of antigen-specific $T$ cell clones. Investigating the expression of OPN receptors on these clones, we found that they expressed $\alpha_{v}$ integrins (data not shown) $v_{6}$-containing CD44 isoforms as well as integrin receptors $\alpha_{4} \beta_{1}$ and $\alpha_{9} \beta_{1}$ for the matricryptic SLAYGLR sequence located in the N-terminal half of thrombin-cleaved OPN (Figure 4D).

\section{OPN Stimulation of T Cell Clones Suppresses Their IL-4 Secretion}

Because of the described Th1 cytokine functions of OPN, we asked how OPN affects Th1 and Th2 cytokine secretion in nickel-specific T cell clones. To obtain OPN secreted by eukaryotic cells best resembling a form of OPN that is found in inflammatory sites and to avoid effects of contaminating lipopolysaccharide, OPN was transfected into the human EBV-encoded nuclear Ag-carcinoma cell line and purified by His-tag (data not shown). When T cell clones were stimulated with recombinant human OPN, IL-4 secretion decreased, but IFN- $\gamma$ expression was not significantly affected (Figure 5). Furthermore, following IFN- $\gamma$ stimulation of the cells, OPN was not significantly modulated. These findings suggest that OPN can modulate antigen-specific $T$ cells to robustly express a Th1 cytokine pattern by suppressing IL-4 secretion.

\section{Antigen-Specific Stimulation of T Cells from TNCB-Sensitized Mice Induces OPN-Specific Production of OPN in Both $\mathrm{CD} 4^{+}$and $\mathrm{CD} 8^{+}$ $T$ Cells}

To validate the in vivo significance of our findings in the human system, we investigated the potential impact of OPN in the murine TNCB/TNBS CHS model. T cells from skin-draining lymph nodes of TNCB-sensitized mice were
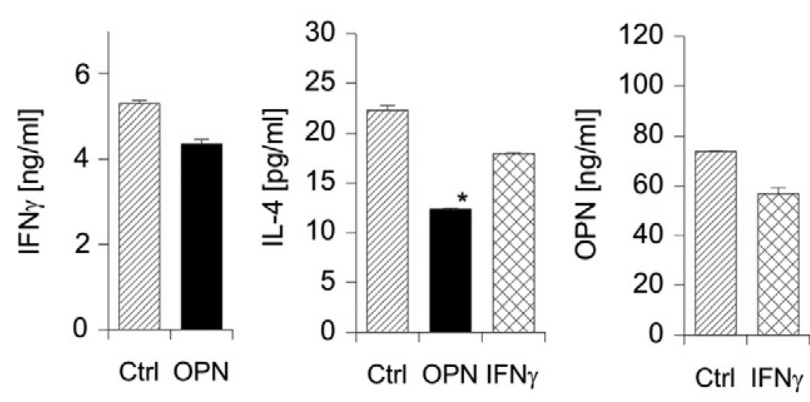

Figure 5. OPN modulates the expression of IL- 4 in nickel-specific $T$ cell clones. $\mathrm{CD} 4{ }^{+} \mathrm{CD} 45 \mathrm{RO}^{+} \mathrm{T}$ cell clones were generated from peripheral blood of nickel-allergic donors, identified by $\mathrm{NiSO}_{4}$ patch-testing, as described in Materials and Methods. Cells were washed and then stimulated with OPN (2 $\mu \mathrm{g} / \mathrm{ml})$ or IFN- $\gamma(200 \mathrm{U} / \mathrm{ml})$ for 48 hours. Cytokine secretion was measured by IL-4, IFN- $\gamma$, or OPN-specific ELISA. A representative experiment from independent experiments with three clones is shown. (Statistically significant, paired $t$-test: ${ }^{*} P<0.05$.) 
A

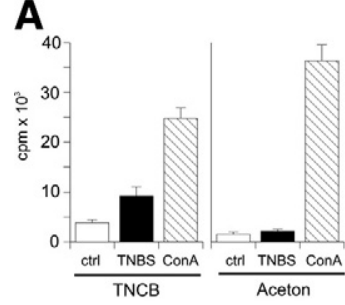

D

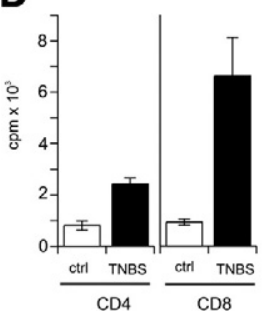

B

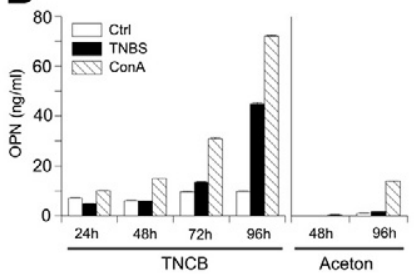

$E$

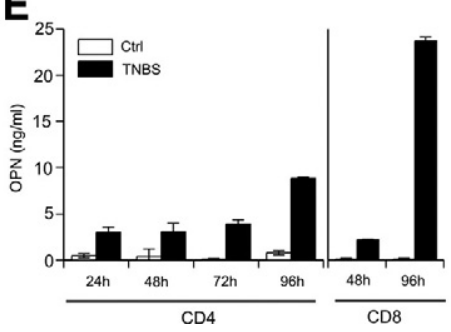

C

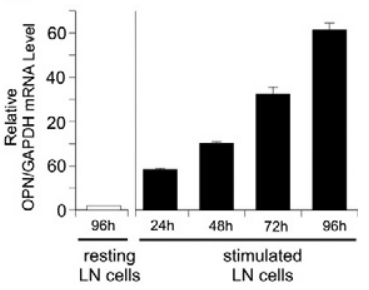

Figure 6. Antigen-specific stimulation of $\mathrm{CHS}$ effector $\mathrm{T}$ cells from sensitized mice induces their OPN secretion. On day $0, \mathrm{C} 57 \mathrm{BL} / 6$ mice were sensitized on the abdomen with $7 \%$ TNCB and challenged with $1 \%$ TNCB on both ears on day 5. Twenty-four hours after challenge, lymph node single-cell suspensions were prepared (AC). Lymph node cells from challenged mice were stimulated with untreated or TNBS-loaded splenic cells or concavalin A (ConA) was added to untreated cells. Proliferation was measured by $\left[{ }^{3} \mathrm{H}\right]$ thymidine uptake $(\mathbf{A})$, secretion of OPN was detected by ELISA (B), and OPN mRNA expression was analyzed by real-time PCR. Data are given as ratio of OPN mRNA to glyceraldehyde3-phosphate dehydrogenase housekeeping gene (GAPDH) (C). D and E: $\mathrm{CD}^{+}{ }^{+}$and $\mathrm{CD}^{+}{ }^{+} \mathrm{T}$ cells were isolated by MACS-negative depletion. Cells were cultured with 30-Gy irradiated, TNBS-loaded spleen cells or unloaded spleen cells as controls (Ctrl). Proliferation was measured by $\left[{ }^{3} \mathrm{H}\right]$ thymidine uptake (D), and secretion of OPN was detected by ELISA (E). The data represent the results of three independent experiments. stimulated with TNBS-loaded splenic cells, which induced OPN secretion by bulk-proliferating lymph node cells on the protein (Figure 6, A and B) and mRNA level (Figure $6 \mathrm{C}$ ). $\mathrm{CD}^{+} \mathrm{T}$ cells are the major effector cells in $\mathrm{CHS}$. We therefore investigated whether $\mathrm{CD}^{+}{ }^{+}$or $\mathrm{CD}^{+} \mathrm{T}$ cells would differ in their OPN-secreting potential (Figure $6, \mathrm{D}$ and $\mathrm{E}$ ). When restimulating the $\mathrm{CD}^{+}$and $\mathrm{CD}^{+}$ population with antigen-loaded irradiated splenic cells, we found that both $\mathrm{CD}^{+}$and $\mathrm{CD}^{+}{ }^{+} \mathrm{T}$ cells proliferating on antigen-specific stimulation produced OPN (Figure $6 \mathrm{E})$. Interestingly, CD8 ${ }^{+} \mathrm{T}$ cells produced more than double the amount of $\mathrm{CD}^{+}{ }^{+}$cells. Our findings indicate that OPN is highly produced by antigen-specific T cells on their activation and that $\mathrm{CD}^{+}$cells produce the highest amounts of OPN in this system.

\section{IFN- $\gamma$ Specifically Induces OPN Expression by Keratinocytes}

Chemokines and cytokines secreted by keratinocytes during their activation in chronic ACD decisively contribute to the inflammatory response. ${ }^{50}$ Because we had observed that keratinocytes that normally express only very low levels of OPN, stained intensely with antibodies against OPN, which increased from acute to chronic $A C D$, we tested the modulation of OPN expression in keratinocyte cultures using a panel of cytokines that are secreted by inflammatory cells in ACD. Using real-time PCR, we found that within 4 hours IFN- $\gamma$ specifically induced high levels of OPN mRNA in keratinocytes. Additionally, IL-4 induced OPN, however, mRNA levels were only slightly beyond the significance level (Figure 7 A). To detect OPN protein produced by keratinocytes, immunostaining of keratinocytes was performed. In contrast to unstimulated cells IFN- $\gamma$-activated keratinocytes stained brightly with anti-OPN monoclonal antibody. When OPNspecific ELISA was performed with supernatants, only IFN- $\gamma$ provoked OPN secretion (Figure 7, B-E). However, levels of OPN were relatively low, which could possibly be explained by OPN binding to CD44 isoforms (Figures 7F and $1, \mathrm{~J}$ and $\mathrm{K}$ ) and $\alpha_{\mathrm{v}}$-integrins (Figure 1, $\mathrm{M}$ and $\mathrm{N}$ ), which are abundantly expressed by keratinocytes. Our findings suggest that OPN expression by keratinocytes is strongly induced by IFN- $\gamma$ and is involved in perpetuation of the antigen-specific immune response through its chemotactic and Th1 cytokine functions.
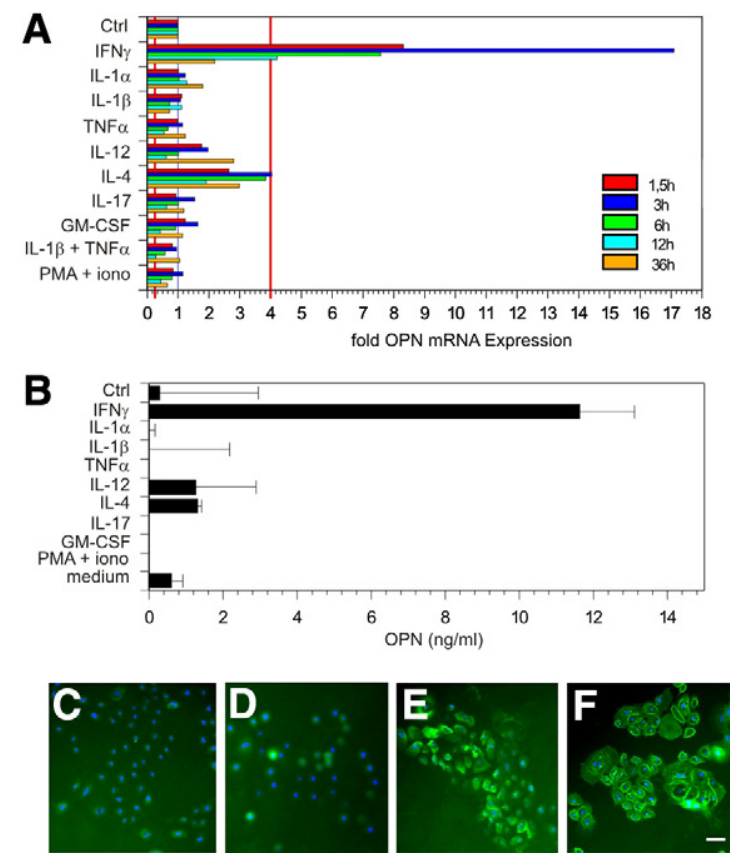

Figure 7. Among proinflammatory cytokines expressed in contact dermatitis IFN- $\gamma$ specifically induces OPN expression in keratinocytes. Human-cultured keratinocytes were stimulated with the indicated proinflammatory cytokines and OPN mRNA expression was measured by real-time PCR at time points $1.5,3,6,12$, and 36 hours after cytokine stimulation (A) or OPN secretion was measured 48 hours after cytokine stimulation (B). Immunohistochemistry was performed with layers of untreated keratinocytes (D) or with IFN- $\gamma$ ( 48 hours) stimulated keratinocytes $(\mathbf{C}, \mathbf{E}$, and $\mathbf{F})$. Cells were stained with primary isotype control antibody (C) or antibodies against OPN (D and E) or CD44s (F). Cy2 (green fluorescent) labeled secondary antibody was used to visualize staining (C-F). Cell nuclei are stained in blue (bisBenzidineH 33342 trihydrochloride; Sigma-Aldrich); bar $=15 \mu \mathrm{m}$. The data represent the results of three independent experiments with keratinocytes from three different donors. 
A

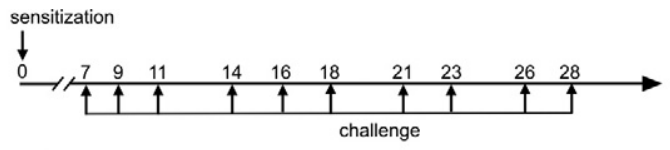

B

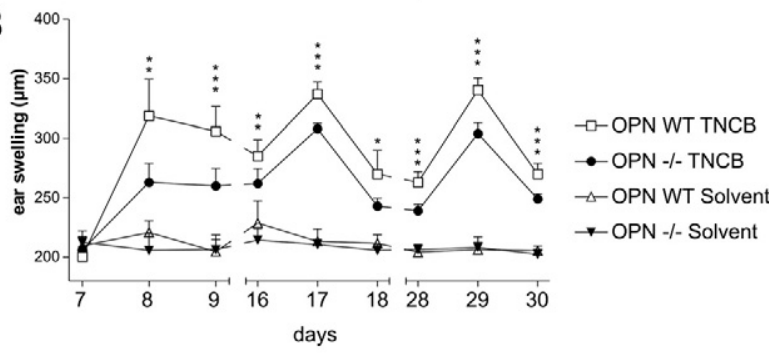

C
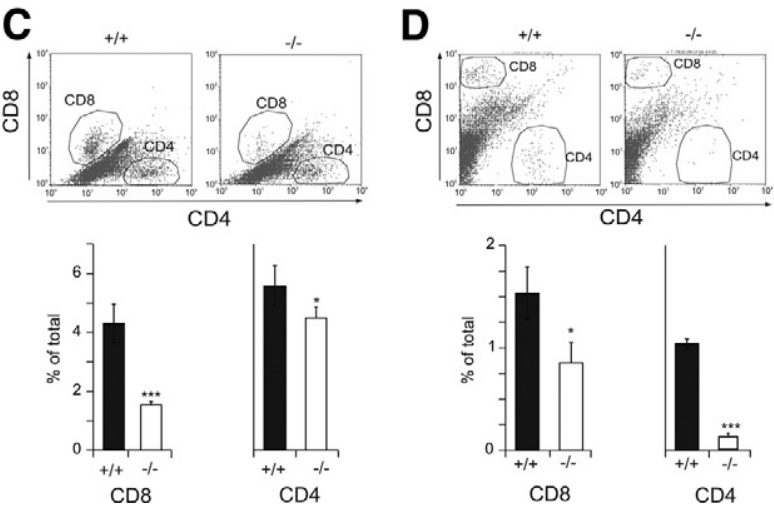

Figure 8. OPN null mice have impaired chronic CHS response. $\mathbf{A}$ and $\mathbf{B}$ : OPN wild-type (WT) and OPN null $(-/-)$ mice were sensitized on the abdominal skin with $100 \mu \mathrm{l}$ of TNCB ( $7 \%$ in acetone). On day 7 , the mice were challenged with $20 \mu \mathrm{l}$ of TNCB on both sides of the ear ( $1 \%$ in acetone). To induce chronification of CHS, the challenge was repeated three times per week for 3 weeks. Control animals were treated by solvent alone. Ear swelling was quantified by dial thickness gauge (Mitutoyo) on days 7 (before first challenge), $8,9,16,17,18,28,29$, and 30. OPN wild-type TNCB: $n=12$, OPN ${ }^{-1-}$ TNCB: $n=5$, OPN wild-type solvent: $n=12, \mathrm{OPN}^{-1-}$ solvent: $n=$ 8 mice. C: OPN wild-type $(+/+)$ and OPN null $(-/-)$ mice were sensitized on the abdominal skin with $100 \mu$ l of $7 \%$ TNCB. After 5 days, the mice were challenged with $20 \mu \mathrm{l}$ of $1 \%$ TNCB on both sides of the ear, and single-cell suspension of ear skin was analyzed for infiltrating $\mathrm{CD} 4^{+}$and $\mathrm{CD} 8^{+}$cells by flow cytometry after 24 hours ( $n=4$ mice). D: Pan T cells were purified from lymph nodes and spleens of OPN wild-type $(+/+)$ and OPN null $(-/-)$ donor mice and adoptively transferred i.v. into syngeneic Rag2 $2^{-/-}$recipient mice. Twelve hours after transfer, recipient mice were sensitized on the abdominal skin with $100 \mu \mathrm{l}$ of $7 \%$ TNCB in acetone or acetone alone. After 5 days, the mice were challenged with $20 \mu \mathrm{l}$ of TNCB (1\% in acetone) on both sides of the ear. Twenty-four hours after challenge, single-cell suspension of ear skin was analyzed by flow cytometry $(60,000$ to 100,000 events) to assess infiltration of $\mathrm{CD}^{+}$and $\mathrm{CD}^{+}(n=3$ recipient mice). (Statistically significant, unpaired $t$-test: $\left.{ }^{*} P<0.05,{ }^{* * *} P<0.01,{ }^{* * * *} P<0.001\right)$. The data represent the results of two independent experiments.

\section{OPN Null Mice Are Impaired in Their Capacity to Mount Chronic CHS Response}

To determine the in vivo importance of OPN expression for the chronification of CHS, we challenged TNCB-sensitized mice every 3 days over a period of 27 days (Figure $8 \mathrm{~A})$. The ear-swelling response was determined 24 and 48 hours after challenge. Compared with wild-type mice, OPN null mice showed a significantly reduced $\mathrm{CHS}$ response (Figure 8B). Over the time period of 27 days, differences between wild-type and OPN null mice were gradually reduced. An explanation could be that other cytokines gradually substitute for the missing OPN. To investigate $\mathrm{T}$ cell-dependent pathomechanism explaining reduced chronic $\mathrm{CHS}$, we investigated the influx of $\mathrm{T}$
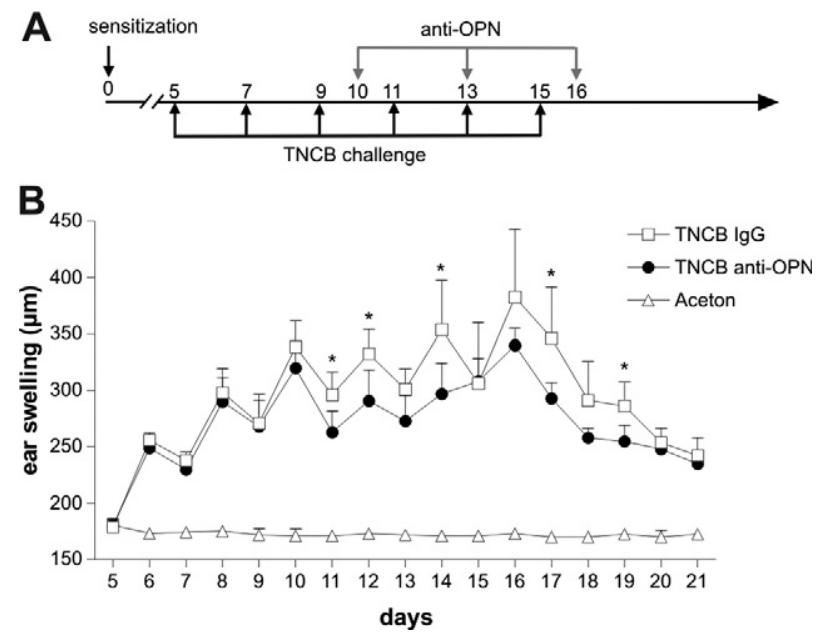

Figure 9. Anti-OPN antibodies suppress established chronic CHS. Mice were sensitized on day 0 with $7 \%$ TNCB in acetone or acetone as control. CHS was elicited with $1 \%$ TNCB or acetone as indicated in $\mathbf{A}$. TNCB sensitized animals were injected i.p. with $400 \mu \mathrm{g}$ of anti-OPN monoclonal antibody or isotype matched control antibody on days 10, 13, and 16 (A and $\mathbf{B})$. Ear swelling was measured daily beginning on day 5 . TNCB IgG: $n=5$, TNCB anti-OPN: $n=$ 5, acetone: $n=8$ mice. (Statistically significant, unpaired $t$-test: ${ }^{*} P<0.05$.)

cells into acute $\mathrm{CHS}$ lesions. In OPN null mice, we found that fewer CD4 and CD8 effector cells enter the inflammatory site (Figure $8 \mathrm{C}$ ). To further confirm that this was at least partially due to a reduced OPN secretion by antigen-specific activated T cells, OPN wild-type, or OPN null T cells were transferred into OPN wild-type RAG2 ${ }^{-1-}$ mice (Figure 8D). The mice that had received the OPN null T cells also showed impaired influx of CD4 and CD8 cells into the elicitation site. In conclusion, our data provide evidence that OPN highly secreted by antigen activated $T$ cells in vitro and in vivo is a central factor for a robust chronic allergic immune response at least in part by attracting $T$ effector cells into the skin.

\section{OPN Antibodies Suppress Established Chronic $\mathrm{CHS}$}

To finally investigate whether OPN could be a therapeutic target, chronic $\mathrm{CHS}$ was elicited in mice and anti OPN mAbs were injected i.p. (Figure 9A). Monoclonal OPN antibodies were able to significantly suppress the established chronic CHS inflammatory response (Figure 9B). Importantly, antibodies were even effective when applied during repeated antigen challenge that induces a very strong inflammatory response. These findings underline the involvement of OPN in chronic inflammatory $\mathrm{CHS}$ responses and hint toward a possible therapeutic application of anti-OPN antibody preparations for chronic unmanageable chronic ACD.

\section{Discussion}

OPN has been shown to have important functions for the induction of a robust Th1/Th17-mediated immunity in antimicrobial response and in autoimmune diseases. ${ }^{13,14,24,34,51}$ Here we demonstrated that OPN is 


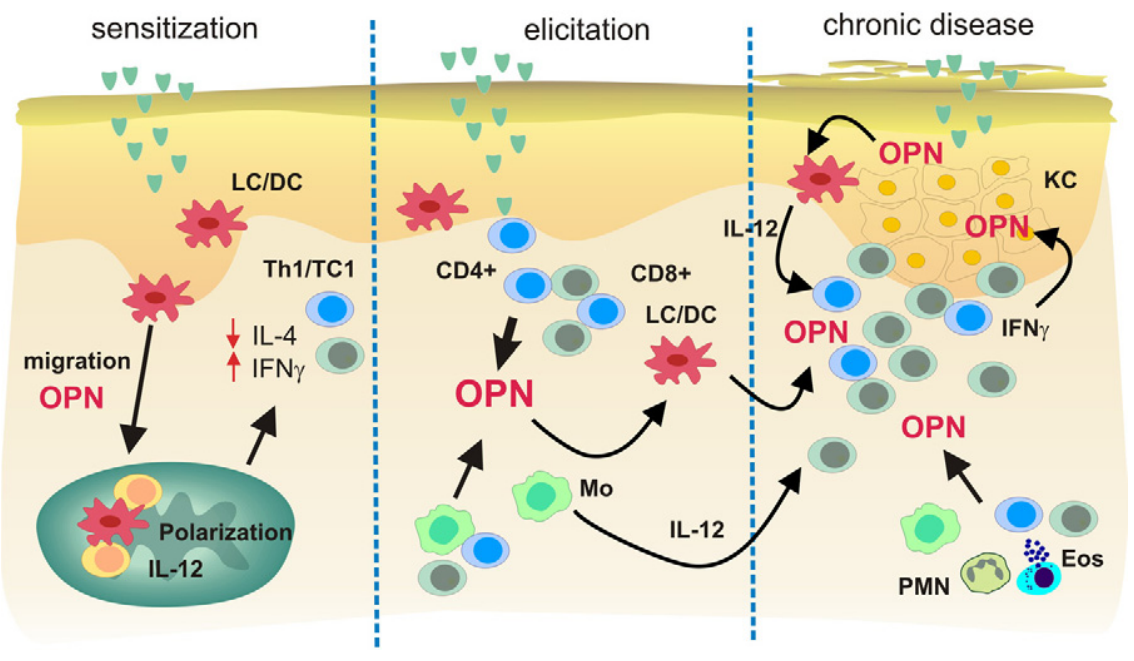

Figure 10. A model for the role of OPN in the chronification of allergic contact dermatitis. During the sensitization-phase OPN interacts with CD44 and $\alpha_{\mathrm{v}}$ integrins on LC/DC to guide them from the skin into skin draining lymph nodes. ${ }^{22}$ Simultaneously OPN induces the polarization of LC/DC toward a Th1-modulating phenotype by inducing their IL-12 secretion. ${ }^{36}$ During the effector phase, OPN is secreted by activated memory $\mathrm{T}$ cells, and as a chemokine, it induces the influx of additional T effector cells, neutrophils, and mast cells. When chronification occurs after repeated application of the allergen, the strong expression of OPN can stabilize the inflammatory response by inducing IL-12 in macrophages and DCs to maintain IFN- $\boldsymbol{\gamma}$-dominated Th1 immune response. Simultaneously, IFN- $\gamma$ secreted by effector cells induces the production of OPN by keratinocytes. Keratinocyte OPN may directly affect the polarization and activation of LCs (epidermal DCs) highly expressed during the induction of chronic ACD, for example, against $\mathrm{NiSO}_{4}$ and use a murine model of chronic ACD to study the implications of OPN secretion for the induction of chronic antigen-specific inflammation of the skin. Having previously shown that OPN is important during the sensitization phase of CHS by its Th1polarizing and chemotactic effect on mDCs, ${ }^{36}$ we here demonstrate that OPN functions as a central cytokine during the elicitation of chronic ACD/CHS when highly induced by antigen-specific $T$ cell activation.

We found that during the elicitation phase of ACD infiltrating $\mathrm{CD}_{45 \mathrm{RO}^{+}}$memory $\mathrm{T}$ cells secrete OPN. Recently, Shinohara et $\mathrm{al}^{24}$ demonstrated that OPN gene expression in activated $T$ cells is regulated by the transcription factor $\mathrm{T}$-bet that controls $\mathrm{CD}^{+}{ }^{+}$helper $\mathrm{T}$ cell commitment toward a Th1 phenotype. Furthermore, Tbet-dependent expression of OPN is essential for CD4 ${ }^{+}$ and $\mathrm{CD}^{+}{ }^{+}$effector cells to develop into Th1/Tc1 cells. We therefore investigated whether OPN expression is a signal induced by antigen-specific activation of effector $T$ cells. When specifically stimulating $\mathrm{CD}^{+}{ }^{+}$or $\mathrm{CD}^{+}{ }^{+} \mathrm{T}$ cells from nickel-allergic donors with $\mathrm{NiSO}_{4}$, we found that both $\mathrm{T}$ cell subsets highly produced SOPN. OPN secreted at inflammatory sites has been shown to have multiple functions. OPN is a chemo-attractant for various types of immune cells, especially monocytes, mDCs, and T cells. ${ }^{22,52,53}$ We therefore propose that during the elicitation phase of ACD OPN attracts additional antigenspecific T cells, monocytes, and DCs (Figure 10). Furthermore, through its cytokine functions OPN induces $\mathrm{IL}-12$ secretion in macrophages simultaneously inhibiting their IL-10 production. ${ }^{51}$ Importantly, we found that OPN is able to induce a Th1-skewing phenotype in myeloidtype DCs by inducing their IL-12 secretion, which may further help to stabilize the Th1 response through antigen presentation by such polarized DCs. ${ }^{36}$ We therefore propose that OPN highly secreted on antigen-specific stimulation of memory $T$ cells affects monocyte and DC functions to stabilize the Th1-dominated immune response (Figure 10).

To further investigate the mechanisms of OPN for T cell function in $\mathrm{CHS}$ nickel-specific T cell clones were gener- ated from the peripheral blood of nickel-allergic donors. To our surprise, in such clones that proliferated specifically, OPN could not be up-regulated by antigen stimulation. We can only speculate that this may occur because such clones were repeatedly restimulated with IL-2 in the process of their generation. These cells may have differentiated into memory $T$ cells that already produce higher amounts of OPN that may not be further up-regulated by TCR activation. This has not been observed previously but will be an interesting topic to investigate in depth in future studies.

However, when comparing different clones, we found that OPN secretion varied among them, correlating with their cytokine-secreting phenotype. We found that clones that secreted very high amounts of OPN secreted low levels of IFN- $\gamma$ but moderate to high amounts of IL-4. Th1-type clones with high IFN- $\gamma$ secretion however, produced less than half the amounts of OPN than the Th2type cells. Interestingly, two clones that produced abundant OPN secreted very low levels of both IL-4 and IFN- $\gamma$, indicating that high OPN levels may suppress these cytokines in an autocrine manner. Because these $T$ cell clones express the IFN- $\gamma$ receptor as well as the OPN receptors $\mathrm{CD} 44$ isoforms and OPN-binding integrins, we tested OPN effects on IL-4 and IFN- $\gamma$ secretion in our clones. When treating clones with recombinant OPN from eukaryotic cells, OPN did not significantly modulate IFN- $\gamma$, however, strongly down modulated IL-4 secretion. These findings indicate that in an inflammatory setting OPN highly secreted by antigen-specific T cells may have Th1 cytokine functions that in a loop-like fashion inhibit IL-4 secretion of effector cells, thereby stabilizing the Th1-dominated inflammatory response. Our data are in accordance to recent findings that demonstrated that OPN administration during the challenge phase of allergic airway diseases decreases established Th2 responses, also by down-modulating IL-4 secretion. ${ }^{21}$ Interestingly, in the human system it was shown that the OPN gene is highly up-regulated during bee venom immunotherapy, which is considered to be effective at least partially by IL-4-inhibiting Th1-skewing effects on the antigen-specific immune response. ${ }^{54}$ 
In the TNCB/TNBS model of murine $\mathrm{CHS}, \mathrm{CD}^{+} \mathrm{T}$ cells have been shown to be the major effector $T$ cells. In this system, both $\mathrm{CD}^{+}$and $\mathrm{CD} 8^{+}$T cells secreted OPN when restimulated by TNBS; however, $\mathrm{CD}^{+} \mathrm{T}$ cells showed stronger antigen-specific proliferation leading to the production of more than twice the amount of OPN that is secreted by the $\mathrm{CD}^{+}$cells, which indicates that OPN is an important factor used by $\mathrm{CD}^{+}$effector T cells. Hur et al ${ }^{34}$ demonstrated that in autoimmune disease of the brain, OPN functions as a prosurvival signal for $T$ cells through OPN promoted activation of $\mathrm{Nf}-\kappa \mathrm{b}$ inhibition of the transcription factor Foxo3a and alteration of the proapoptotic proteins Bim, Bak, and Bax. It seems likely that OPN antiapoptotic functions are implicated in the chronification of $\mathrm{ACD} / \mathrm{CHS}$, inhibiting the elimination of T effector cells.

In skin biopsies of ACD we found that OPN was gradually up-regulated by keratinocytes as the disease became more chronic. Activation of keratinocytes is an important pro inflammatory factor during the elicitation of $\mathrm{ACD} / \mathrm{CHS}{ }^{50}$ Various cytokines secreted in the process of the inflammatory response are known to activate keratinocytes. ${ }^{55}$ Because OPN expression by keratinocytes has not been investigated so far, we stimulated keratinocyte cultures by cytokines typically expressed in ACD lesions and found that IFN- $\gamma$ quickly and strongly induced keratinocyte OPN mRNA expression. IL-4 in contrast induced only a modest increase in OPN expression in keratinocytes with quantitative mRNA levels only just beyond significance. When determining sOPN in supernatants of cytokine stimulated keratinocytes, we found that cells, when considering the total cell number in cultures, produced relatively moderate amounts of OPN. In addition to $\alpha_{v}$ integrins, keratinocytes highly express CD44 isoforms that have been described to bind OPN. We therefore propose that high amounts of the OPN secreted by keratinocytes are bound on the cell surface by OPN receptors. The staining pattern of cultured keratinocytes as well as the staining of keratinocytes in ACD lesions suggests that keratinocytes may contain an intracellular form of OPN, ${ }^{18,56}$ its function for keratinocytes, however, remaining subject for future investigations. Functionally OPN secreted by keratinocytes may have implications for the activation of LCs, the DCs of the epidermis, as we have shown that OPN is able to activate LCs on their emigration from the epidermis, and induces their IL-12 secretion. ${ }^{22}$ This supports our hypothesis that keratinocyte sOPN may be a factor that supports the stabilization of the chronic Th1 response by polarizing Th1-skewing DCs. Because in various cell systems OPN has been shown to have antiapoptotic capacities, ${ }^{34,57-60}$ one could additionally speculate that keratinocytes use OPN as an antiapoptotic factor, when they are attacked by Fas-expressing $\mathrm{CD}^{+}$effector $\mathrm{T}$ cells, which however has to be subject of further investigations.

When studying the role of OPN for the induction of chronic CHS in vivo, we found that OPN null mice respond with less severe chronic CHS than wild-type mice, which indicates that OPN is an important factor for the chronification of $\mathrm{T}$ cell-mediated inflammatory response in vivo. Indeed, in OPN null mice, less $\mathrm{CD}^{+}$and $\mathrm{CD}^{+}$effector $\mathrm{T}$ cells were found to invade the challenged skin. Further- more, we found that the OPN secreted by the antigenactivated $T$ cells was a central factor explaining the reduced allergic response, because RAG2 ${ }^{-1-}$ mice established with OPN null T cells were also less effective in attracting T cells to the inflamed skin. In conclusion, these findings provide strong evidence that highly secreted sOPN from effector T cells is a major factor for robust establishment of chronic antigen-specific driven allergic inflammation.

The importance of these data are further underlined by our finding that fully established chronic $\mathrm{CHS}$ can be suppressed by anti OPN antibodies. The antibody used in this study was designed to bind to the matricryptic SLAYGLR (SVVYGLR in human) sequence of OPN that is only exposed on protease cleavage of OPN. We found that T cells in $\mathrm{CHS}$ express receptors for full-length OPN such as $\alpha_{v}$ integrins and CD44 isoforms and further $\alpha_{4} \beta_{1}$ and $\alpha_{9} \beta_{1}$ integrin that interact with the SLAYGLR sequence of cleaved OPN. Previous work has established that noncleaved and thrombin cleaved forms of OPN are present at inflammatory sites and that especially cleaved OPN that contains the SLAYGLR sequence contributes to cell-mediated inflammation, eg, in T cell-mediated liver disease and rheumatoid arthritis. ${ }^{61,62}$ We speculate that in CHS OPN protease cleavage at sites of chronic inflammation may enhance the inflammatory response by attracting $\alpha_{4}$ and $\alpha_{9}$ integrin-expressing effector cells. Therefore, in addition to general OPN-neutralizing functions, the monoclonal antibody used here may be especially effective by blocking the matricryptic epitope of cleaved OPN, making it an interesting tool for therapeutic approaches in therapy resistant chronic ACD. Interestingly, by OPN antibody suppression of CHS (Figure 9B) was not as effective as total deletion of OPN in OPN null mice (Figure 9B). This may be explained in part by the fact that OPN monoclonal antibodies are able to deplete only SOPN, but the function of intracellular isoforms of OPN is not affected by the antibody.

In conclusion, our data support a model (Figure 10) in which OPN has an important function for Th1 cell-mediated skin inflammation, which may open the perspective to use anti-OPN antibody preparations for the treatment of therapy refractory $T$ cell-mediated skin disease. During the sensitization phase of CHS, OPN is involved in guiding DCs toward skin draining lymph nodes, simultaneously skewing them toward Th1-polarizing abilities. When ACD/CHS is elicited, OPN is highly secreted by antigen-specific effector cells, attracting further inflammatory cells and activating monocytes to secrete IL-12 and simultaneously inhibiting their $\mathrm{IL}-10$ secretion. Attracted $T$ effectors secrete IFN- $\gamma$, which then activates keratinocytes to produce OPN that may help T effectors to invade the epidermis and damage keratinocytes. Keratinocyte-derived OPN may influence epidermal LCs to consolidate Th1-driven response, especially as the disease progresses to become chronic.

\section{Acknowledgments}

We thank Thomas Ahrens for providing the recombinant OPN and his support in all questions of protein biochem- 
istry. We thank Hermann-Josef Thierse for his kind support in generation of nickel-specific clones and Stefan F. Martin for fruitful discussions and critical review of the manuscript. Josef Schlick and Jan Scheurmann contributed to parts of this work by their expert technical assistance. The MPIIIB10 (1) monoclonal antibody developed by Solursh/Franzen was obtained from the Developmental Studies Hybridoma Bank developed under the auspices of the National Institute of Child Health and Human Development and maintained by the University of lowa, Department of Biological Sciences.

\section{References}

1. Diepgen TL, Coenraads PJ: The epidemiology of occupational contact dermatitis. Int Arch Occup Environ Health 1999, 72:496-506

2. Kimber I, Dearman RJ: Allergic contact dermatitis: the cellular effectors. Contact Dermatitis 2002, 46:1-5

3. Cavani A, Girolomoni G: Immune mechanisms in allergic contact dermatitis. Georgetown, TX, Landes Bioscience, 2005, pp 1-14

4. Hogan DJ, Dannaker CJ, Maibach HI: The prognosis of contact dermatitis. J Am Acad Dermatol 1990, 23:300-307

5. Thyssen JP, Johansen JD, Menne T: Contact allergy epidemics and their controls. Contact Dermatitis 2007, 56:185-195

6. Frosch PJ, Menne T, Lepoittevin JP: Contact dermatitis. Berlin, Springer, 2007, pp 135-150

7. Romani N, Ebner S, Tripp CH, Flacher V, Koch F, Stoitzner P: Epidermal Langerhans cells-changing views on their function in vivo. Immunol Lett 2006, 106:119-125

8. Kaplan DH, Jenison MC, Saeland S, Shlomchik WD, Shlomchik MJ: Epidermal Langerhans cell-deficient mice develop enhanced contact hypersensitivity. Immunity 2005, 23:611-620

9. Kissenpfennig A, Henri S, Dubois B, Laplace-Builhe C, Perrin P, Romani N, Tripp CH, Douillard P, Leserman L, Kaiserlian D, Saeland S, Davoust J, Malissen B: Dynamics and function of Langerhans cells in vivo: dermal dendritic cells colonize lymph node areas distinct from slower migrating Langerhans cells. Immunity 2005, 22:643-654

10. Cavani A, Albanesi C, Traidl C, Sebastiani S, Girolomoni G: Effector and regulatory $T$ cells in allergic contact dermatitis. Trends Immunol 2001, 22:118-120

11. Martin SF, Jakob T: From innate to adaptive immune responses in contact hypersensitivity. Curr Opin Allergy Clin Immunol 2008, 8:289-293

12. Pichler BJ, Kneilling M, Haubner R, Braumuller $H$, Schwaiger $M$, Rocken M, Weber WA: Imaging of delayed-type hypersensitivity reaction by PET and 18F-galacto-RGD. J Nucl Med 2005, 46:184-189

13. O'Regan AW, Nau GJ, Chupp GL, Berman JS: Osteopontin (Eta-I) in cell mediated immunity: teaching an old dog new tricks. Immunol Today 2000, 21:475-478

14. Denhardt DT, Noda M, O'Regan AW, Pavlin D, Berman JS: Osteopontin as a means to cope with environmental insults: regulation of inflammation, tissue remodeling, and cell survival. J Clin Invest 2001, 107:1055-1061

15. Wang KX, Denhardt DT: Osteopontin: role in immune regulation and stress responses. Cytokine Growth Factor Rev 2008, 19:333-345

16. Buback F, Renkl AC, Schulz G, Weiss JM: Osteopontin and the skin: -Multiple emerging roles in cutaneous biology and pathology. Exp Dermatol 2009, 18:750-759

17. Cantor $\mathrm{H}$, Shinohara ML: Regulation of $\mathrm{T}$ helper cell lineage development by osteopontin: the inside story. Nat Rev Immunol 2009, 9:137-141

18. Shinohara ML, Lu L, Bu J, Werneck MB, Kobayashi KS, Glimcher LH, Cantor $\mathrm{H}$ : Osteopontin expression is essential for interferon- $\alpha$ production by plasmacytoid dendritic cells. Nat Immunol 2006, 7:498506

19. Shinohara ML, Kim JH, Garcia VA, Cantor H: Engagement of the type I interferon receptor on dendritic cells inhibits $T$ helper 17 cell development: role of intracellular osteopontin. Immunity 2008, 29: 68-78

20. Shinohara ML, Kim HJ, Kim JH, Garcia VA, Cantor H: Alternative translation of osteopontin generates intracellular and secreted isoforms that mediate distinct biological activities in dendritic cells. Proc Natl Acad Sci USA 2008, 105:7235-7239

21. Xanthou G, Alissafi T, Semitekolou M, Simoes DC, Economidou E, Gaga M, Lambrecht BN, Lloyd CM, Panoutsakopoulou V: Osteopontin has a crucial role in allergic airway disease through regulation of dendritic cell subsets. Nat Med 2007, 13:570-578

22. Weiss JM, Renkl AC, Maier CS, Kimmig M, Liaw L, Ahrens T, Kon S, Maeda M, Hotta H, Uede T, Simon JC: Osteopontin is involved in the initiation of cutaneous contact hypersensitivity by inducing Langerhans and dendritic cell migration to lymph nodes. J Exp Med 2001 194:1219-1229

23. Murugaiyan G, Mittal A, Weiner HL: Increased osteopontin expression in dendritic cells amplifies IL-17 production by $\mathrm{CD} 4^{+} \mathrm{T}$ cells in experimental autoimmune encephalomyelitis and in multiple sclerosis. J Immunol 2008, 181:7480-7488

24. Shinohara ML, Jansson M, Hwang ES, Werneck MB, Glimcher LH, Cantor H: T-bet-dependent expression of osteopontin contributes to T cell polarization. Proc Natl Acad Sci USA 2005, 102:17101-17106

25. Wong CK, Lit LC, Tam LS, Li EK, Lam CW: Elevation of plasma osteopontin concentration is correlated with disease activity in patients with systemic lupus erythematosus. Rheumatology (Oxford) 2005, 44:602-606

26. Comabella M, Pericot I, Goertsches R, Nos C, Castillo M, Blas NJ, Rio $\mathrm{J}$, Montalban X: Plasma osteopontin levels in multiple sclerosis. J Neuroimmunol 2005, 158:231-239

27. Xu G, Nie H, Li N, Zheng W, Zhang D, Feng G, Ni L, Xu R, Hong J, Zhang JZ: Role of osteopontin in amplification and perpetuation of rheumatoid synovitis. J Clin Invest 2005, 115:1060-1067

28. Sato T, Nakai T, Tamura N, Okamoto S, Matsuoka K, Sakuraba A Fukushima T, Uede T, Hibi T: Osteopontin/Eta-1 up-regulated in Crohn's disease regulates the Th1 immune response. Gut 2005, 54:1254-1262

29. Chabas D, Baranzini SE, Mitchell D, Bernard CC, Rittling SR, Denhardt DT, Sobel RA, Lock C, Karpuj M, Pedotti R, Heller R, Oksenberg JR, Steinman L: The influence of the proinflammatory cytokine, osteopontin, on autoimmune demyelinating disease. Science 2001, 294:17311735

30. Kitamura M, Iwabuchi K, Kitaichi N, Kon S, Kitamei H, Namba K, Yoshida K, Denhardt DT, Rittling SR, Ohno S, Uede T, Onoe K: Osteopontin aggravates experimental autoimmune uveoretinitis in mice. J Immunol 2007, 178:6567-6572

31. Jansson M, Panoutsakopoulou V, Baker J, Klein L, Cantor H: Cutting edge: attenuated experimental autoimmune encephalomyelitis in eta1/osteopontin-deficient mice. J Immunol 2002, 168:2096-2099

32. Tanaka K, Morimoto J, Kon S, Kimura C, Inobe M, Diao H, Hirschfeld G, Weiss JM, Uede T: Effect of osteopontin alleles on $\beta$-glucaninduced granuloma formation in the mouse liver. Am J Pathol 2004, 164:567-575

33. Renkl AC, Wussler J, Eggers T, Maier CS, Ahrens T, Martin S, Liaw L, Kon S, Uede T, Hirschfeld G, Simon JC, Weiss JM: Th1 cytokine-like properties of osteopontin on T cells, macrophages, and dendritic cells in type 1 immune responses. Allergy Clin Immunol Int 2004, Supp 1:97-102

34. Hur EM, Youssef S, Haws ME, Zhang SY, Sobel RA, Steinman L: Osteopontin-induced relapse and progression of autoimmune brain disease through enhanced survival of activated T cells. Nat Immunol 2007, 8:74-83

35. Sodek J, Batista Da Silva AP, Zohar R: Osteopontin and mucosal protection. J Dent Res 2006, 85:404-415

36. Renkl AC, Wussler J, Ahrens T, Thoma K, Kon S, Uede T, Martin S, Simon JC, Weiss JM: Osteopontin functionally activates dendritic cells and induces their differentiation towards a Th-1 polarizing phenotype. Blood 2005, 106:946-955

37. Schulz G, Renkl AC, Seier A, Liaw L, Weiss JM: Regulated osteopontin expression by dendritic cells decisively affects their migratory capacity. J Invest Dermatol 2008, 128:2541-2544

38. Kon S, Yokosaki Y, Maeda M, Segawa T, Horikoshi Y, Tsukagoshi H, Rashid MM, Morimoto J, Inobe M, Shijubo N, Chambers AF, Uede T: Mapping of functional epitopes of osteopontin by monoclonal antibodies raised against defined internal sequences. J Cell Biochem 2002, 84:420-432

39. Weiss JM, Renkl AC, Denfeld RW, de Roche R, Spitzlei M, Schöpf E, Simon JC: Low-dose UVB radiation perturbs the functional expres- 
sion of B7.1 and B7.2 co-stimulatory molecules on human Langerhans cells. Eur J Immunol 1995, 25:2858-2862

40. Moulon C, Wild D, Dormoy A, Weltzien HU: MHC-dependent and -independent activation of human nickel-specific $\mathrm{CD} 8^{+}$cytotoxic $\mathrm{T}$ cells from allergic donors. J Invest Dermatol 1998, 111:360-366

41. Denfeld RW, Hollenbaugh D, Fehrenbach A, Weiss JM, von Leoprechting A, Mai B, Voith U, Schöpf E, Aruffo A, Simon JC: CD40 is functionally expressed on human keratinocytes. Eur $\mathrm{J}$ Immunol 1996, 26:2329-2334

42. Liaw L, Birk DE, Ballas CB, Whitsitt JS, Davidson JM, Hogan BL: Altered wound healing in mice lacking a functional osteopontin gene (spp1). J Clin Invest 1998, 101:1468-1478

43. Weiss JM, Sleeman J, Renkl AC, Dittmar HC, Termeer CT, Taxis S, Howells N, Hofmann M, Köhler G, Schöpf E, Ponta H, Herrlich P, Simon JC: An essential role for CD44 variant isoforms in epidermal Langerhans cell and blood dendritic cell function. J Cell Biol 1997, 137:1137-1147

44. Livak KJ, Schmittgen TD: Analysis of relative gene expression data using real-time quantitative PCR and the $2^{-\Delta \Delta C T}$ method. Methods 2001, 25:402-408

45. Young MF, Kerr JM, Termine JD, Wewer UM, Wang MG, McBride OW, Fisher LW: cDNA cloning, mRNA distribution and heterogeneity, chromosomal location, and RFLP analysis of human osteopontin (OPN). Genomics 1990, 7:491-502

46. Ahrens T, Pertz O, Haussinger D, Fauser C, Schulthess T, Engel J: Analysis of heterophilic and homophilic interactions of cadherins using the C-Jun/c-Fos dimerization domains. J Biol Chem 2002, 277:19455-19460

47. Chiocchetti A, Indelicato M, Bensi T, Mesturini R, Giordano M, Sametti S, Castelli L, Bottarel F, Mazzarino MC, Garbarini L, Giacopelli F, Valesini G, Santoro C, Dianzani I, Ramenghi U, Dianzani U: High levels of osteopontin associated with polymorphisms in its gene are a risk factor for development of autoimmunity/lymphoproliferation. Blood 2004, 103:1376-1382

48. Patarca R, Freeman GJ, Singh RP, Wei FY, Durfee T, Blattner F, Regnier DC, Kozak CA, Mock BA, Morse HC3: Structural and functional studies of the early $\mathrm{T}$ lymphocyte activation 1 (Eta-1) gene: definition of a novel T cell-dependent response associated with genetic resistance to bacterial infection. J Exp Med 1989, 170:145-161

49. Moulon C, Vollmer J, Weltzien HU: Characterization of processing requirements and metal cross-reactivities in T cell clones from patients with allergic contact dermatitis to nickel. Eur J Immunol 1995, 25:3308-3315

50. Albanesi C, Cavani A, Scarponi C, Girolomoni G: Multiple roles of keratinocytes in allergic contact dermatitis: immune mechanisms in allergic contact dermatitis. Edited by A Cavani and G Girolomoni. Georgetown, TX, Landes Bioscience, 2005, pp 104-112
51. Ashkar S, Weber GF, Panoutsakopoulou V, Sanchirico ME, Jansson M, Zawaideh S, Rittling SR, Denhardt DT, Glimcher MJ, Cantor H: Eta-1 (osteopontin): an early component of type-1 (cell-mediated) immunity. Science 2000, 287:860-864

52. O'Regan AW, Chupp GL, Lowry JA, Goetschkes M, Mulligan N, Berman JS: Osteopontin is associated with T cells in sarcoid granulomas and has $\mathrm{T}$ cell adhesive and cytokine-like properties in vitro. J Immunol 1999, 162:1024-1031

53. Bruemmer D, Collins AR, Noh G, Wang W, Territo M, Arias-Magallona S, Fishbein MC, Blaschke F, Kintscher U, Graf K, Law RE, Hsueh WA: Angiotensin $\mathrm{II}$-accelerated atherosclerosis and aneurysm formation is attenuated in osteopontin-deficient mice. J Clin Invest 2003, 112:1318-1331

54. Konno S, Golden DB, Schroeder J, Hamilton RG, Lichtenstein LM, Huang SK: Level of osteopontin is increased after bee venom immunotherapy. J Allergy Clin Immunol 2005, 115:1317-1318

55. Albanesi C, Scarponi C, Giustizieri ML, Girolomoni G: Keratinocytes in inflammatory skin diseases. Curr Drug Targets Inflamm Allergy 2005, 4:329-334

56. Zohar R, Suzuki N, Suzuki K, Arora P, Glogauer M, McCulloch CA, Sodek J: Intracellular osteopontin is an integral component of the CD44-ERM complex involved in cell migration. J Cell Physiol 2000, 184:118-130

57. Burdo TH, Wood MR, Fox HS: Osteopontin prevents monocyte recirculation and apoptosis. J Leukoc Biol 2007, 81:1504-1511

58. Lee JL, Wang MJ, Sudhir PR, Chen GD, Chi CW, Chen JY: Osteopontin promotes integrin activation through outside-in and inside-out mechanisms: OPN-CD44V interaction enhances survival in gastrointestinal cancer cells. Cancer Res 2007, 67:2089-2097

59. Rice J, Courter DL, Giachelli CM, Scatena M: Molecular mediators of $\alpha_{\mathrm{v}} \beta_{3}$-induced endothelial cell survival. J Vasc Res 2006, 43:422-436

60. Cook AC, Tuck AB, McCarthy S, Turner JG, Irby RB, Bloom GC Yeatman TJ, Chambers AF: Osteopontin induces multiple changes in gene expression that reflect the six "hallmarks of cancer" in a model of breast cancer progression. Mol Carcinog 2005, 43:225-236

61. Ohshima S, Yamaguchi N, Nishioka K, Mima T, Ishii T, UmeshitaSasai M, Kobayashi H, Shimizu M, Katada Y, Wakitani S, Murata N, Nomura S, Matsuno H, Katayama R, Kon S, Inobe M, Uede T, Kawase I, Saeki Y: Enhanced local production of osteopontin in rheumatoid joints. J Rheumatol 2002, 29:2061-2067

62. Diao H, Kon S, Iwabuchi K, Kimura C, Morimoto J, Ito D, Segawa T, Maeda M, Hamuro J, Nakayama T, Taniguchi M, Yagita H, Van Kaer L, Onoe K, Denhardt D, Rittling S, Uede T: Osteopontin as a mediator of NKT cell function in T cell-mediated liver diseases. Immunity 2004, 21:539-550 